\title{
INCLUSÃO DE PESSOAS COM DEFICIÊNCIA VISUAL POR MEIO DA CARTOGRAFIA TÁTIL E MAQUETE
}

\section{Ana Flávia Santos*, Artemis D. do N. Alves*, Maria Elisabete R. F. Gasparetto}

Resumo: No contexto de inclusão de pessoas com deficiência visual, destaca-se o uso da Cartografia Tátil, que pode ser definida como a ciência, a arte e a técnica de transpor uma informação visual de tal maneira que resulte em um documento que possa ser utilizado por essas pessoas (CARMO, 2009). A construção de instrumentos táteis como mapas e maquetes visa sobretudo transformar informações geográficas bidimensionais para planos tridimensionais, que se aproximam mais da realidade, possibilitando a criação de imagens mentais e maior noção espacial. Neste sentido, esse projeto teve como objetivos, apresentar a construção artesanal de um mapa tátil e de uma maquete do CEPRE e aprimorar esses instrumentos táteis com o auxílio de pessoas com deficiência visual. Realizou-se pesquisa exploratória, por meio da construção de instrumentos táteis. Os usuários com deficiência visual tiveram acesso aos instrumentos táteis na sala de espera enquanto aguardavam o atendimento. O mapa tátil e a maquete, proporcionaram o reconhecimento e apropriação dos espaços do CEPRE. Para garantir a acessibilidade utilizou-se de materiais simples, contrastantes e com relevo. Com base nas opiniões dos usuários, as devidas alterações serão realizadas procurando o aprimoramento do mapa tátil e da maquete.

Palavras-chave: Deficiência Visual, Mapa Tátil, Acessibilidade

\section{Introdução}

A cartografia tátil é um ramo específico da Cartografia, que se ocupa da confecção de mapas e outros produtos que podem ser lidos por pessoas com deficiência visual $(\mathrm{LOCH}, 2008)$. Os instrumentos táteis podem funcionar tanto como recursos educativos, quanto como facilitadores de mobilidade em campus universitário. Decorrente disso, esse projeto teve como objetivos: apresentar a construção artesanal de um mapa tátil e de uma maquete do CEPRE (Centro de Estudos e Pesquisas em Reabilitação "Prof. Dr. Gabriel O.S. Porto") e aprimorar esses instrumentos por meio do auxílio de pessoas com deficiência visual.

\section{Resultados e Discussão}

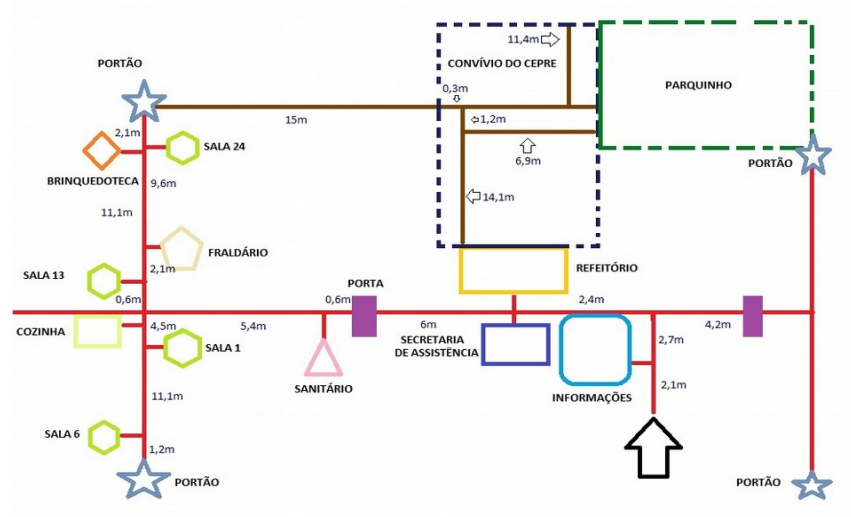

Figura 1. Projeto do Mapa Tátil

Realizou-se pesquisa exploratória, por meio da construção de instrumentos táteis. Foi construído um mapa tátil, bem como uma maquete do CEPRE, visando a leitura de pessoas com deficiência visual. Para garantir a acessibilidade utilizou-se de materiais simples, contrastantes e com relevo. As legendas, siglas e nomes foram escritos em tinta e no sistema braile. Os instrumentos foram apresentados às pessoas com deficiência visual com o intuito que transmitissem suas percepções espaciais com o uso do mapa tátil e da maquete, a compreensão desses instrumentos, a opinião sobre as texturas, cores e, tamanhos dos objetos representados. Baseados nessas percepções e opiniões as devidas alterações serão realizadas procurando o aprimoramento do mapa tátil e da maquete. As representações gráficas em relevo como o mapa e a maquete tornaram-se recursos importantes para a localização de ambientes e objetos e consequentemente para a inclusão de pessoas com deficiência visual.

\section{Conclusões \\ Os instrumentos táteis são recursos de} tecnologia assistiva por auxiliarem a promover a independência e ampliar a capacidade de pessoas com deficiência visual. Os instrumentos táteis proporcionaram a essas pessoas, o reconhecimento e apropriação dos espaços do CEPRE. A opinião desses usuários possibilitará o aprimoramento dos instrumentos táteis construídos.

\section{Agradecimentos}

Agradecemos à Profa M. Elisabete R. F.Gasparetto pela oportunidade, aconselhamento e encorajamento contínuo durante pesquisa; Aos usuários do CEPRE pelas percepções e opiniões que possibilitarão um aprimoramento dos materiais construídos e agradecemos ao Programa de Bolsas do Serviço de Atendimento ao Estudante da Unicamp pelo financiamento deste projeto.

CARMO, W. R. "Cartografia Tátil Escolar: Experiências com a Construção de Materiais Didáticos e com a Formação Continuada de Professores". Dissertação (Mestrado em Geografia) Departamento de Geografia - $\quad$ FFLCH, USP. 2009.

LOCH, R. E. N. Cartografia Tátil: mapas para deficientes visuais. Portal da Cartografia. Londrina, v.1, n.1, maio/ago., p. 35 - 58, 2008. 